\title{
A Study of Alcohol Drinking Behavior of Parents of Secondary 6 Students at Chaibadan Wittaya School, Lopburi.
}

\author{
Taksaon Numdee
}

Chaibadan Wittaya School, Lamnarai, Chaibadan District, Lopburi 15130

\begin{abstract}
This study had two objectives as follows: (1) to study the alcohol drinking behavior of parents of Secondary 6 students at Chaibadan Wittaya School, Lopburi, and (2) to report on the situation of alcohol consumption and related problems of parents of Secondary 6 students at Chaibadan Wittaya School, Lopburi. The sample group in this study consisted of parents of Secondary 6 students at Chaibadan Wittaya School, Lopburi, semester 1 of the academic year 2021, totaling 6 classrooms, number of parents 39 people. The study instrument was the alcohol drinking behavior questionnaire among the parents of Secondary 6 students at Chaibadan Wittaya School, Lopburi. The statistics used to analyze the data were averages.

The results showed that, the study of alcohol consumption behavior of parents of Secondary 6 students at Chaibadan Wittaya School, Lopburi, by using the alcohol drinking behavior questionnaire of parents of Secondary 6 students at Chaibadan Wittaya School, Lopburi, it was related to the ability to control oneself by finding ways to relieve stress and discomfort without drinking alcohol at 46.15 percent. This is consistent with a study by Prapa and Usa, that predicted alcohol-free intentions among undergraduate students at a university in southern Thailand. It was found that the attitude was positively correlated with the intention not to drink alcohol at a statistically significant level ( $p$-value $<0.01$ ). The reference group's intent to quit drinking was correlated with the level of alcohol cessation, consistent with Eisen's theory of planned behavior. It states that the behavior conforms to the reference group in the practice of that behavior, with the reference group being an important determinant, the person's intention to act and whether the person commits any behavior. When the person has positively assessed the effect of the action and the person believes that the reference group is important to the practice of that behavior, that is, friends and family are important to the sample. The study found that the subjects prioritized their families when they thought they should reduce, and stop drinking alcohol.

Their family members wanted them to focus on other activities instead of drinking alcohol in their spare time, such as exercise, sports, reading, etc., which accounted for 38.46 percent. Consistent with Nan and in accordance with the study of Prapa and Usa that examined factors that predict alcohol-free intentions of undergraduate students at a university in the south of Thailand. In their study, they found that the reference group's preference behavior was statistically positively correlated with the intention to abstain from alcohol. It can be discussed from the theory of planned behavior that reference group conformity is the perception of social norms or other people's beliefs that affect one's or one's actions. This perception is influenced by the people around them that the group is important to themselves. Literature review found that people with alcohol dependence seriously and permanently want to quit drinking because of family, partner, friends, etc. In the study, they were able to control themselves to do other activities instead of drinking alcohol in their spare time, which accounted for 35.89 percent. It is consistent with a study by Sukuma that examined the effect of a cognitive behavioral therapy program with social support on readiness to prevent relapse and nonrelapse behavior among alcoholic patients. It was also found that social support can build mental readiness of patients to prevent alcohol dependence, by giving alcoholics an intention to prevent relapses and perceived their ability to prevent relapses. The Planned behavior theory states that one's efficacy to stop drinking alcohol is the perception of the person and the drinker's ability to stop drinking alcohol. For example, has patience, perseverance, does not give up, shows the ability to stop drinking alcohol. All of these will seriously affect the
\end{abstract}


intention of implementing alcohol-cessation behaviors with a clearer goal to quit drinking. This results from having a positive attitude that drives the intention to behave according to reference groups such as family and friends, as well as the perception of the ability to clearly control alcohol abstinence behavior.

Keyword: Drinker, Regular drinking, Heavy drinking, Questionnaire

\section{Introduction}

Recently, drinking alcohol is a global public health problem. It has intensified as it a readily available and popular drink all over the world for all ages. The 2014 global alcohol consumption data by the World Health Organization found that more than $38 \%$ of the world's population consumed alcohol regularly, with 3.3 million deaths a year from alcohol consumption. Thailand is ranked $40^{\text {th }}$ in the world. The 2014 Thai population alcohol consumption behavior survey found that Thai people aged 15 years and over consumed 32.3 percent of alcoholic beverages, and the working age group (25-59 years), the drinking rate was 38.2 percent higher than the other groups. Men had a drinking rate five times higher than that of women, 53.0 percent. The reason from the alcohol connoisseurs found that among the undergraduate students in Bangkok the most preferred to drink alcohol. They say that drinking to relax and socialize with friends and that when drinking makes you assertive, drink is unique, drink is comfortable. From the Global Action Plan report for the prevention of non-communicable diseases (NCDs) by the World Health Organization (WHO), they identified alcohol consumption as one of the four major risk factors that should be prevented in all countries around the world, they have a goal by 2020 to reduce the risk associated with alcohol by $10 \%$. In addition, there are Sustainable Development Goals (SDGs) under the 2030 National Agenda, an announcement by the United Nations (UN) has identified alcohol as a major obstacle in relation to 13 of the 17 main goals.

The situation of alcohol consumption is constantly changing and therefore the risk of alcohol consumption behavior should be monitored in various issues. All this is to guide the policy formulation of the control and prevention of health and social problems, the provision of medical services, and public health and the evaluation of measures related to the control and prevention of problems caused by alcohol consumption. Therefore, the study was interested to report on the situation of alcohol consumption and related problems among parents of Secondary 6 students at Chaibadan Wittaya School, Lopburi. The study, which used a specific randomized sampling scheme using classrooms as the sampling unit for May-July 2021, had a total sample size of 39 out of 314 households.

\section{Methods}

Firstly, to study the alcohol drinking behavior of parents of Secondary 6 students at Chaibadan Wittaya School, Lopburi. Secondly, to report on the situation of alcohol consumption and related problems of parents of Secondary 6 students at Chaibadan Wittaya School, Lopburi.

\section{Scope of the study}

Population and sample group

Population

The population of this study consisted of parents of Secondary 6 students at Chaibadan Wittaya School, Lopburi, semester 1 of the academic year 2021, number of 10 classrooms, number of parents 314 people.

The sample groups in this study were parents of Secondary 6 students at Chaibadan Wittaya School, Lopburi, the first semester of the academic year 2021, number of 1 classroom, number of parents 39 people. 


\section{Duration}

May to July 2021

\section{Data analysis}

1. Collect answers from all 39 questionnaires.

2. Find the basic statistic such as average.

\section{Data analysis statistics}

Basic statistical values such as average, standard deviation, calculated using the excel program

\section{Results}

\section{Data analysis results}

Part 1 General information of parents of Secondary 6 students at Chaibadan Wittaya School, Lopburi, who answered the alcohol drinking behavior questionnaire.

Table 1 General data of the respondents to the alcohol drinking behavior of parents.

\begin{tabular}{l|c|c}
\hline \multicolumn{1}{c|}{ Content } & total (peoples) & $\%$ \\
\hline 1. Sex & & 58.97 \\
Male & 23 & 41.03 \\
2. Status & 16 & 10.25 \\
Single & 4 & 74.34 \\
Married & 29 & 15.38 \\
Widowed & 6 & 15.38 \\
3. Educational qualification & & 64.10 \\
Under bachelor's degree & 6 & 20.51 \\
Bachelor's degree & 25 & 0 \\
Postgraduate & 8 & 0 \\
4. Ages & & 0 \\
Under 15 years old & 0 & 100 \\
16- 20 years old & 0 & 0 \\
21- 30 years old & 39 & \\
Over 30 years old & & \\
\hline
\end{tabular}

From the table 1, the sample group is 58.47 percent male, 41.03 percent female, 10.25 percent single, 74.34 percent married, 15.38 percent widowed; Educational qualification, 15.38 percent lower than bachelor's degree, 64.16 percent bachelor's degree, 20.51 percent higher than bachelor's degree; The average age is more than 30 years, 900 percent. 
Part 2 The results of a study on alcohol drinking behavior of parents of Secondary 6 students at Chaibadan Wittaya School, Lopburi.

Table 2 Alcohol Drinking Behavior

1. Have you ever had a drink or alcohol?

2. Have you been drinking a lot at once in the last 12 months.

3. Have you ever drunk and driven a vehicle?

4. Your family wants you to stop drinking alcohol on purpose even if your friends are here to talk you out of it.

5. Your family would like you to carefully avoid situations or places where alcohol is drunk on the end of the month, a liquor store near your place of residence, or an office.

6. Your family would like you to concentrate on other activities instead of drinking alcohol in your spare time, such as sports, reading, etc.

7. Your family wants you to set a target to reduce alcohol intake.

8. Your family wants you to plan a total denial of alcohol when you're invited to drink.

9. Your family wants you to relax by listening to music, watching football, playing sports instead of drinking alcohol when things get uncomfortable.

10. Your family would like you to choose a friend who doesn't drink alcohol

11. Your family wants you to be confident you can stop drinking alcohol?

12. Your family thinks you should reward yourself when you finish drinking alcohol.

13. You can control yourself to drink alcohol even if your friends invite you.

14. You can control yourself to avoid situations or work places where you drink alcohol, like the end of the month, a liquor store near a place to stay.

15. You can control yourself against alcohol after work.

16. You can control yourself to do other activities than drink alcohol in your spare time.

17. You can keep on meeting your goal of reducing your alcohol intake.

18. You can control your own plan to reject anyone who's been strongly persuaded to drink alcohol.

19. You can control yourself by finding ways to relieve stress and discomfort without drinking alcohol.

20. You can control yourself and make sure that 'I can stop drinking alcohol completely.'
Averages and Estimate

\begin{tabular}{|c|c|c|c|c|}
\hline $\begin{array}{c}\text { strongly } \\
\text { agree }\end{array}$ & agree & unsure & disagree & $\begin{array}{l}\text { strongly } \\
\text { disagree }\end{array}$ \\
\hline 25.64 & 35.89 & 20.51 & 12.82 & 5.12 \\
\hline 10.25 & 7.69 & 38.46 & 15.38 & 28.20 \\
\hline 12.82 & 17.94 & 17.94 & 23.07 & 28.20 \\
\hline 15.38 & 33.33 & 38.46 & 7.69 & 5.12 \\
\hline 23.07 & 30.76 & 28.20 & 12.82 & 5.12 \\
\hline 38.46 & 28.20 & 17.94 & 7.69 & 7.69 \\
\hline 33.33 & 30.76 & 20.51 & 7.69 & 7.69 \\
\hline 28.20 & 20.51 & 33.33 & 12.82 & 5.12 \\
\hline 30.76 & 48.71 & 7.69 & 5.12 & 7.69 \\
\hline 10.25 & 28.20 & 38.46 & 10.25 & 12.82 \\
\hline 25.64 & 28.20 & 20.51 & 17.94 & 7.69 \\
\hline 15.38 & 23.07 & 43.58 & 10.25 & 7.69 \\
\hline 30.76 & 48.71 & 17.94 & 0 & 2.56 \\
\hline 33.33 & 33.33 & 33.33 & 0 & 0 \\
\hline 33.33 & 35.89 & 28.20 & 2.56 & 0 \\
\hline 35.89 & 28.20 & 35.89 & 0 & 0 \\
\hline 30.76 & 43.58 & 23.07 & 2.56 & 0 \\
\hline 30.76 & 33.33 & 30.76 & 5.12 & 0 \\
\hline 46.15 & 38.46 & 15.38 & 0 & 0 \\
\hline 25.64 & 46.15 & 23.07 & 5.12 & 0 \\
\hline 26.79 & 32.05 & 26.66 & 7.94 & 6.53 \\
\hline
\end{tabular}




\section{Conclusion}

The results of a study on alcohol drinking behavior of parents of Secondary 6 students at Chaibadan Wittaya School, Lopburi showed the following results. A study of alcohol drinking behavior of parents of Secondary 6 students at Chaibadan Wittaya School, Lopburi, using the Alcohol Drinking Behavior Questionnaire, the effect was related to self-control by finding ways to relieve stress and discomfort. It was found that those who chose not to drink alcohol accounted for 46.15 percent, consistent with the study of Prapa and Usa that examined factors predicting the intention not to drink alcohol among undergraduate students at a university in southern Thailand. The study found that attitude was statistically positively correlated with intention not to drink alcohol ( $\mathrm{p}$-value $<0.01$ ). The reference group's intent to quit drinking was correlated with the level of alcohol cessation, consistent with Eisen's theory of planned behavior. Planned behavior theory states that reference-group conformance in behavior practice has that reference group is an important determinant of a person's willingness to perform it. The person assessed the effect of the action positively and the person believed the reference group was important to the behavioral practice, that is, friends and family that were important to the sample. The study found that the subjects prioritized their families when they thought they should reduce or quit drinking alcohol.

By 38.46 percent of the sample, their families would like them to focus on other activities instead of drinking alcohol in their spare time such as exercise, sports, reading, etc. It is consistent with the study of Nan and the study of Prapa and Usa that examined the predictors of alcohol-free intentions among undergraduate students at a university in southern Thailand. The study found that the reference group's conformity behavior was statistically positively associated with the intention to abstain from alcohol, although it can be debated from planned behavior theory. Referral behavior is the perception of social norms or other people's beliefs as affecting one's or one's actions. This perception is influenced by the people around them that the group is important to themselves. Literature review found that in those who are addicted to alcohol seriously and permanently want to quit drinking because of family factors, couples, friends, etc.

And they were able to control themselves to do other activities instead of drinking alcohol in their spare time for 35.89 percent.

It is consistent with the Sukuma study that examined the effect of a cognitive behavioral therapy program with social support on the readiness to prevent addiction and non-addiction behavior among alcoholic patients. The study found that social support can increase the mental readiness of patients to prevent readdiction by giving alcoholics an addiction-prevention intention and anti-relapse prevention awareness. The Planned Behavior Theory found that the perception of alcohol cessation was the perceived ability of individuals and alcohol drinkers to be able to stop drinking alcohol. For example, have patience, perseverance, persistence, and show your ability to stop drinking alcohol. All of these will seriously affect the intention of implementing alcohol-cessation behaviors with a clearer goal to quit drinking. This results from having a positive attitude that drives the intention to behave according to reference groups such as family and friends, as well as the perception of the ability to clearly control alcohol abstinence behavior.

\section{Acknowledgements}

The completion of this undertaking could not have been possible without the participation and assistance of so many people whose names may not all be enumerated. Their contributions are sincerely appreciated. However, I would like to express their deep gratitude and appreciation particularly to the parents of Secondary 6 students at Chaibadan Wittaya School, Lopburi, for agreeing to provide the information, which is extremely crucial to make the study possible. 


\section{References}

กาญจนา แก้วสุวรรณ. (๒๕๕๐). ผลของโปรแกรมเสริมสร้างสมรรถนะแห่งตนในการปฏิเสธการดื่มต่อพฤติกรรมการดื่มแอลกอฮอล์ของวัยรุ่น อำเภอทุ่งหัวช้าง จังหวัดลำพูน, วิทยานิพนธ์พยาบาลศาสตรมหาบัณฑิต, บัณฑิตวิทยาลัย : มหาวิทยาลัยเชียงใหม่, หน้า ง-จ.

จรรยา ใจหนุน, (๒๕๕๑). ผลของโปรแกรมการบำบัดทางความคิดและพฤติกรรมต่อพฤติกรรมการดื่มแอลกอฮอล์ของผู้ติดสุรา โรงพยาบาลสมเด็จพระเจ้าตากสิน มหาราช จังหวัดตาก, วิทยานิพนธ์พยาบาลศาสตรมหาบัณฑิต, บัณฑิตวิทยาลัย : มหาวิทยาลัยเชียงใหม่, หน้า ง-จ.

จุฬารัตน์ สุวรรณเมฆ, (๒๕๕๖) ผลของโปรแกรมการเรียนรู้แบบมีส่วนร่วมต่อความรู้เกี่ยวกับมะเร็งปากมดลูก เจตคติ และความตั้งใจ ในการรับการตรวจคัดกรอง มะเร็งปากมดลูกของสตรีที่แต่งงานแล้ว, วิทยานิพนธ์ปริญญาพยาบาลศาสตรมหาบัณฑิต บัณฑิตวิทยาลัย : มหาวิทยาลัยเชียงใหม่.

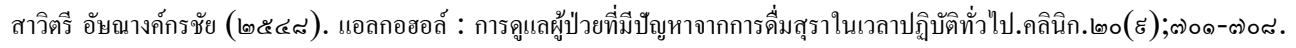

สุวรรณา อรุณพงศ์ไพศาล. (๒๕๕๓). รายงานการทบทวนองค์ความรู้เรื่องมาตรการในการป้องกันและแก้ไขปัญหาจากแอลกอฮอล์.กรุงเทพฯ.สถาบันวิจัยและระบบ สาธารณสุข.

ดวงเดือน เนตรกระจ่าง, (๒๕๕๑) ผลของโปรแกรมการเสริมสร้างพลังอำนาจแบบกลุ่มต่อพฤติกรรมการดื่มแอลกอฮอล์ของผู้ป่วยโรคจิตจากสุรา โรงพยาบาล สวนปรุง จังหวัดเชียงใหม่, วิทยานิพนธ์พยาบาลศาสตรมหาบัณฑิต,บัณฑิตวิทยาลัย : มหาวิทยาลัยเชียงใหม่, หน้า ง-จ.

ปนัดดา ธีระเชื้อ, (๒๕๕๐), ผลของโปรแกรมการควบคุมตนเองต่อพฤติกรรมการดื่มของผู้ติดสุราใน โรงพยาบาลวังเหนือ จังหวัดลำปาง, วิทยานิพนธ์ พยาบาลศาสตรมหาบัณฑิต, บัณฑิตวิทยาลัย : มหาวิทยาลัยเชียงใหม่, หน้า ง-จ.

พจนานุกรมพุทธศาสตร์ พระธรรมปิฎก (ป.อ.ปยุต̣ โต), (๒๕๕๖) พจนานุกรมพุทธศาสตร์ ฉบับประมวลธรรม, พิมพ์ครั้งที่ ๑๒,กรุงเทพมหานคร : จุพาลงกรณ์ราช วิทยาลัย, หน้า ๘๕.

มาโนช หล่อตระกูล และปราโมทย์ สุคนิชย์, (๒๕๕๘). จิตเวชศาสตร์ รามาธิบดี, กรุงเทตมหานคร : บียอนด์เอ็น-เทอร์ไตรซ์.

ศรัณย์ อั้งสกุล, (๒๕๕๑). ผลของโปรแกรมส่งเสริมสมรรถนะแห่งตนต่อความตั้งใจในการใช้ถุงยางอนามัยของนักเรียนอาชีวศึกษาเพศหญิงในภาคใต้, วิทยานิพนธ์ พยาบาลศาสตร์มหาบัณฑิต, บัณฑิตวิทยาลัย : จุฬาลงกรณ์ มหาวิทยาลัย, หน้า ง.

สุกุมา แสงเดือนฉาย, การศึกษาพฤติกรรมการดื่มสุรา สภาพแวดล้อมทางครอบครัว และครอบครัว ผลกระทบจากการดื่มสุราและเจตคติต่อการดื่มสุราของผู้ป่วยดื่มสุรา. สุพรรณ ไชยวรรณะ และศรีไตร โปธา สุตรรณ ไชยวรรณะ, (๒๕๕๐). ผลของโปรแกรมเสริมสร้างสมรรถนะแห่งตนในการปฏิเสธการดื่มต่อพฤติกรรม การดื่ม แอลกอฮอล์ของผู้ที่ดื่มแบบมีปัญหาที่มารับบริการในโรงพยาบาลแม่สรวย จังหวัดเชียงราย, วิทยานิพนธ์พยาบาลศาสตร์ มหาบัณฑิต,บัณฑิตวิทยาลัย : มหาวิทยาลัยเชียงใหม่, หน้า ง-จ.

ศรีไตร โปธา, (๒๕๕๐). ผลของโปรแกรมเสริมสร้างสมรรถนะแห่งตนในการปฏิเสธการดื่มต่อพฤติกรรมการดื่มแอลกอฮอล์ของผู้ที่เป็นโรคติดสุราในโรงพยาบาล บ้านธิ จังหวัดลำพูน, วิทยานิพนธ์พยาบาลศาสตรมหาบัณฑิต, บัณฑิตวิทยาลัย : มหาวิทยาลัยเชียงใหม่, หน้า ง-จ.

อวัสดา จันทร์แสนทอ, $($ ๒๕๑). ปัจจัยส่งเสริมและผลกระทบจากการติดสุราของสตรี, วิทยานิพนธ์พยาบาลศาสตรมหาบัณฑิต, บัณฑิตวิทยาลัย : มหาวิทยาลัยเชียงใหม่,

Goodner, B., (1994). Alcoholism : Care of the psychiatric patient. Concepts of Psychiatric Nursing,(Texas : Skidmonre-Roth,

Gelder, M., Mayou, R., \& Cowen, P., (2001). The misuse of alcohol and drugs. Textbook of psychiatry, 4th ed

Arthen : Oxford University press, 536-579.

Saunders, J. B., (2004). National alcohol policy in Australia. The first national conference: Alcohol Consumption and related problem in Thailand. 24th -25th May 2004 Prince Palace Hotel. Bangkok.

Sadock, B.J., \& Sadock, V.A., (2003). Synopsis of psychiatry : Behavioral sciences clinical psychiatry, 9th ed,

Philadelphia : Lippincott.

Bandura, A., (1997). Self-efficacy : The exercise of control, (New York : W.H. Freeman and Company.. Ajzen \& Fishbein, (1980). Understanding Attitudes and Predicting Social Behavior. New Jersy :

Prentice Hall Imc,. 